\title{
Sistem Penentu Calon Penerima Beasiswa Menggunakan Metode Smarter dan Forward Chaining
}

\author{
Fadly $^{1}$,Yulia Darmi ${ }^{2}$, Dedy A. Prabowo ${ }^{3}$ \\ ${ }^{1,2}$ Program Studi Teknik Informatika, Universitas Muhammadiyah Bengkulu \\ Email : fadly@yahoo.com
}

\begin{abstract}
This research aims to create a program to help facilitate the school in determining the students who are eligible for a scholarship. SMA Muhammadiyah 4 Kota Bengkulu serve as research place. The selection process of scholarship recipients in SMA Muhammadiyah 4 Kota Bengkulu is equipped with various criteria, such as family economy, family dependent, child status, School Achievement, out-ofschool education and discipline. It should be noted in the assessment of the criteria and must be relevant because it will basically affect the outcome. In making this Program we use Visual Basic 6.0 software and apply SMARTER Inference Forward Chaining method. The results obtained from this study, have met the criteria desired by the SMA Muhammadiyah 4 Kota Bengkulu and the use of this method is considered effective to be used to anticipate the similarity of the ranking. So that the selection process of scholarship recipients in SMA Muhammadiyah 4 Bengkulu City on target.
\end{abstract}

Keyword : Decision support system, Simple MultiAtribute Rating Technique Exploiting Rank (SMARTER), Forward Chaining

Intisari-Penelitian ini bertujuan membuat program untuk membantu memudahkan pihak sekolah dalam menentukan siswa yang berhak mendapatkan beasiswa. SMA Muhammadiyah 4 Kota Bengkulu dijadikan sebagai tempat penelitian. Proses seleksi calon penerima beasiswa di SMA Muhammadiyah 4 Kota Bengkulu dilengkapi dengan berbagai kriteria, seperti ekonomi keluarga, tanggungan keluarga, status anak, Prestasi Sekolah, prstasi luar sekolah dan kedisiplinan. Hal tersebut perlu diperhatikan dalam perhitungan penilaian terhadap kriteria dan harus relevan karena pada dasarnya akan berpengaruh pada hasil akhirnya. Dalam pembuatan Program ini kami menggunakan perangkat lunak Visual Basic 6.0 dan menerapkan metode SMARTER inferensi Forward Chaining. Hasil yang diperoleh dari penelitian ini, telah memenuhi kriteria yang diinginkan oleh pihak SMA Muhammadiyah 4 Kota Bengkulu dan penggunaaan Metode ini dinilai efektif digunakan untuk mengantisipasi kesamaan hasil perankingan. Sehingga proses seleksi calon penerima beasiswa di SMA Muhammadiyah 4 Kota Bengkulu tepat sasaran.

Kata kunci : Sistem pendukung keputusan, Simple Multi-Atribute Rating Technique Exploiting Rank (SMARTER), Forward Chaining

\section{PENDAHULUAN}

Di setiap lembaga pendidikan khususnya SMA Muhammadiyah 4 Kota Bengkulu banyak sekali beasiswa yang ditawarkan kepada siswa yang berprestasi, untuk mendapatkan beasiswa tersebut maka harus sesuai dengan aturan-aturan yang telah ditetapkan. Menurut Moh Rudi, Achmad Ubaidillah (2014) kriteria yang digunakan dalam menentukan calon penerima beasiswa, adalah sebagai berikut.

1. Ekonomi keluarga (rendah, menengah, atas)

2. Tanggungan keluarga ( $>=5$ anak, 4 anak, 3 anak, 2 anak, 1 anak)

3. Status Anak (yatim piatu, yatim, piatu, normal)

4. Prestasi sekolah (1-3 besar/3,75-4, 4-5 besar/3,5-3,74, 5-8 besar/3-3,4, 8-10 be$\mathrm{sar} / 2,75-2,9,>10 \mathrm{besar} />2.75$ )

5. Prestasi luar sekolah (internasional, nasional, daerah, lokal)

6. Kedisiplinan (Disiplin, Cukup, malas).

Metode Smarter (Simple Multi-Attribute Rating Technique Exploiting Ranks) merupakan modifikasi dari metode Smart (Simple Multi- 
Attribute Rating Technique) yang diusulkan oleh Edwards dan Baron (1994) dalam Citra (2011), dimana kedua metode ini digunakan untuk menentukan bobot dari setiap kriteria dalam suatu pengambilan keputusan. Bobot setiap kriteria menentukan tingkat kepentingan dari kriteria tersebut.

Dari kriteria diatas, dapat di jadikan sebagai tolak ukur untuk melakukan proses penyaringan data siswa pada SMA Muhammadiyah 4 Kota Bengkulu yang akan terpilih sebagai penerimah beasiswa prestasi.

Forward Chaining adalah metode pencarian/ penarikan kesimpulan yang berdasarkan pada data atau fakta yang ada menuju ke kesimpulan, penelusuran dimulai dari fakta yang ada lalu bergerak maju melalui premis-premis untuk menuju ke kesimpulan/bottom up reasoning.

Hasil dari proses metode Metode Smarter (Simple Multi-Attribute Rating Technique Exploiting Ranks) berupa bobot dari kategori dan kemudian diproses dengan menggunakan metode Forward Chaining, dimana bobot tersebut mendapatkan point tersendiri apabila mendapatkan bobot tertinggi, maka akan menerima beasiswa nomor satu, sesuai dengan ketentuan yayasan yakni SMA Muhammadiyah 4 Kota Bengkulu. Proses penghitungan bobot penilaian tersebut dihitung menggunakan logika metode Smarter dan hasil diproses dengan metode forward chaining.

Proses yang dilakukan selama ini dilakukan pada SMA Muhammadiyah 4 Kota Bengkulu dengan menghitung nilai siswa yang terlalu banyak sehingga berkas calon penerimaan beasiswa terlalu menumpak dan kemunginan tercecer, serta memperhatikan kriteria-kriteria lain, hal ini penulis anggap kurang efektif dan kurang efisien waktu.

Berdasarkan latar belakang diatas maka peneliti tertarik melakukan penelitian dengan judul "Sistem Penentu Calon Penerima Beasiswa Menggunakan Metode Smarter (Simple MultiAtribute Rating Technique Exploiting Rank) Dan Forward Chaining".

\section{TINJAUAN PUSTAKA}

\section{A. Beasiswa}

Pada dasarnya, beasiswa adalah penghasilan bagi yang menerimanya. Hal ini sesuai dengan ketentuan pasal 4 ayat (1) UU PPh/2000. Disebutkan pengertian penghasilan adalah tambahan kemampuan ekonomis dengan nama dan dalam bentuk apa pun yang diterima atau diperoleh dari sumber Indonesia atau luar Indonesia yang dapat digunakan untuk konsumsi atau menambah kekayaan Wajib Pajak (WP). Karena beasiswa biasa diartikan menambah kemampuan ekonomis bagi penerimanya, berarti beasiswa merupakan penghasilan (Henry Wibowo, sistem pendukung keputusan untuk menentukan penerima beasiswa bank bri menggunakan FMADM (studi kasus: mahasiswa fakultas teknologi industri Universitas Islam Indonesia), 2009).

\section{B. Metode Smarter}

Metode Smarter (Simple Multi-AttributeRating Technique Exploiting Ranks) merupakan modifikasi dari metode SMART (Simple MultiAttribute Rating Technique) yang diusulkan oleh Edwards dan Baron (1994) dalam Citra (2011), dimana kedua metode ini digunakan untuk menentukan bobot dari setiap kriteria dalam suatu pengambilan keputusan. Bobot setiap kriteria menentukan tingkat kepentingan dari kriteria tersebut. Rumus metode SMARTER secara umum.

Bobot $W$ didapat dari :

$$
\begin{aligned}
& \sum_{i}^{R}-{ }_{1} W_{\mathrm{I}} U_{(1)} \forall \boldsymbol{\imath}=1 \ldots \ldots \ldots . . n \\
& W_{k}=(1 / k) \sum_{i}^{k}-k(1 / 2) \ldots \ldots \ldots . .
\end{aligned}
$$

Dimana Wj adalah nilai skala pembobotan kriteria ke-j dari k kriteria, dan Uij adalah nilai utility / alternatif i pada kriteria j. adapun nilai utility ini diperoleh dari skala pembobotan dari masing-masing sub criteria.

Ada 2 hal yang mendasari metode SMARTER ini (menurut Edward dan Barron dalam Citra, 2011), yaitu: 
1. Teknik yang sederhana lebih mudah digunakan sehingga lebih memungkinkan untuk digunakan oleh pembuat keputusan.

2. Teknik yang mudah lebih memungkinkan untuk mendapatkan keputusan yang dapat diandalkan.

Yang membedakan antara metode SMARTER dan metode SMART adalah masalah pembobotan. Pada metode SMARTER, bobot dihitung dengan menggunakan rumus pembobotan RankOrder Centroid (ROC). ROC ini didasarkan pada tingkat kepentingan atau prioritas dari kriteria. Pembobotan ROC didapat dengan prosedur matematika sederhana dari prioritas. Ide dasarnya dapat diilustrasikan dengan kasus 2 atribut A dan B. Jika A rangking pertama maka bobotnya harus berada antara 0,5 dan 1 sehingga titik tengah dari interval $(0,75)$ diambil sebagai bobot perkiraaan, yang merupakan dasar dari sebuah prinsip komitmen minimum. Seperti juga bobot B akan menjadi 0,25 (merupakan titik tengah antara 0,5 dan 0 ). Prosedur ini dapat dirumuskan sebagai berikut (jika ada $\mathrm{k}$ atribut) :

$$
\begin{aligned}
& \mathrm{w} 1=(1+1 / 2+1 / 3+\ldots . .+1 / \mathrm{k}) / \mathrm{k} \\
& \mathrm{w} 2=(0+1 / 2+1 / 3+\ldots .+1 / \mathrm{k}) / \mathrm{k} \\
& \mathrm{w} 3=(0+0+1 / 3+\ldots .+1 / \mathrm{k}) / \mathrm{k} \\
& \mathrm{wk}=(0+0+0+\ldots \ldots . .+1 / \mathrm{k}) / \mathrm{k}
\end{aligned}
$$

contoh: 2 atrribut

$$
\begin{aligned}
& \mathrm{w} 1=(1+1 / 2) / 2=0,75 \\
& \mathrm{w} 2=(0+1 / 2) / 2=0,25
\end{aligned}
$$

contoh : 3 attribut

$$
\begin{aligned}
& \mathrm{w} 1=(1+1 / 2+1 / 3) / 3=0,6111 \\
& \mathrm{w} 2=(0+1 / 2+1 / 3) / 3=0,2777 \\
& \mathrm{w} 3=(0+0+1 / 3) / 3=0,1111
\end{aligned}
$$

Keuntungan dari metode SMARTER ini adalah pada metode SMARTER melibatkan usaha/ effort yang kecil dari pembuat keputusan

Langkah-langkah metode SMARTER adalah:

1. Identifikasi permasalahan yang ada.

Dengan melihat akar permasalahan dan batasan-batasan yang ada agar nantinya tidak me- nyimpang dari tujuan yang ingin dicapai.

2. Tentukan alternatif

3. Tentukan attribut / kriteria

4. Memberikan peringkat untuk setiap kriteria.

5. Menghitung penilaian terhadap setiap alternatif

Kriteria merupakan acuan yang digunakan dalam menentukan calon penerima beasiswa. Semakin banyak criteria yang digunakan maka semakin ketat seleksi yang dilakukan untuk mendapatkan beasiswa. Sehingga pemberian beasiswa diharapkan benar-benar tepat sasaran.

Tabel 1. Kriteria dan Pembobotan Seleksi

\begin{tabular}{|c|l|c|c|c|c|c|c|}
\hline No & Kriteria & W1 & W2 & W3 & W4 & W5 & Bobot \\
\hline 1 & $\begin{array}{l}\text { Pendidikan } \\
\text { Agama Islam }\end{array}$ & 1 & $1 / 2$ & $1 / 3$ & $1 / 4$ & $1 / 5$ & 0.37 \\
\hline 2 & Matematika & 0 & $1 / 2$ & $1 / 3$ & $1 / 4$ & $1 / 5$ & 0.23 \\
\hline 3 & $\begin{array}{l}\text { Pendidikan } \\
\text { Kewarganegaraan }\end{array}$ & 0 & 0 & $1 / 3$ & $1 / 4$ & $1 / 5$ & 0.16 \\
\hline 4 & Bahasa Indonesia & 0 & 0 & 0 & $1 / 4$ & $1 / 5$ & 0.11 \\
\hline 5 & Bahasa Inggris & 0 & 0 & 0 & 0 & $1 / 5$ & 0.07 \\
\hline
\end{tabular}

\section{Metode Forward Chaining}

Forward chaining (Proboyekti dkk, 2009) adalah metode pencarian/penarikan kesimpulan yang berdasarkan pada data atau fakta yang ada menuju ke kesimpulan, penelusuran dimulai dari fakta yang ada lalu bergerak maju melalui premis-premis untuk menuju ke kesimpulan/bottom up reasoning.

Forward chaining (Honggowibowo, 2009) merupakan grup dari multiple inferensi yang melakukan pencaria $\mathrm{n}$ dari suatu masalah kepada solusinya. Forward chaining adalah data-driven karena inferensi dimulai dengan informasi yang tersedia dan baru konklusi diperoleh.

Menggunakan himpunan aturan kondisi - aksi. Dalam metode ini, data digunakan untuk menentukan aturan mana yang akan dijalankan, kemudian aturan tersebut dijalankan Aplikasi yang akan dibuat juga diintegrasikan dengan metode Forward Chaining yaitu penalaran fakta untuk mencapai kesimpulan merupakan proses yang dikendalikan oleh data. 


\section{Visual Basic 6.0}

Menurut Daryanto (2003, hal. 13), Visual basic adalah suatu development tools untuk membangun aplikasi dalam lingkungan Windows. Dalam pengembangan aplikasi, Visual Basic menggunakan pendekatan Visual untuk merancang user interface dalam bentuk form, sedangkan untuk kodingnya membangun dialek bahasa Basic yang cenderung mudah dipelajari.

\section{E. Konsep Perancangan Database}

Database adalah mekanisme yang digunakan untuk menyimpan informasi atau data yang kita gunakan sehari-hari untuk berbagai alasan pengguna dapat menyimpan data secara terorganisasi (Mulyono, 2008).

Adapun istilah yang sering digunakan dalam perancangan database adalah sebagai berikut:

1. Entity adalah tempat, orang atau kejadian serta, konsep yang informasinya direkam.

2. Atribut adalah elemen data yang menunjang suatau atribut.

3. Data Value adalah data aktual yang disimpan pada sebuah atribut.

4. Record adalah elemen yang saling berkaitan yang menginformasikan suatu entity secara lengkap.

5. File ialah kumpulan record yang sejenis dimana panjang elemen sama, atribut yang sama dan data value yang berbeda datanya.

6. Database adalah kumpulan dan file yang membentuk suatu bangunan.

\section{METODOLOGI PENELITIAN}

\section{A. Populasi dan Sampel}

Penelitian ini dilaksanakan di SMA Muhammadiyah 4 Kota Bengkulu dengan mengambil populasi siswa kelas 2 sebanak 80 orang. Penentuan sampel dalam penelitian ini menggunakan Metode Smarter (Simple Multi-Atribute Rating Technique Exploiting Rank) dan Forward Chaining, menca- ri yang terbaik dari yang terbaik. Sehingga seluru siswa yang telah mendaftarkan diri untuk mengambil beasiswa prestasi, yang berjumlah 40 orang.

B. Perancangan Database

1) DFD (Data Flow Diagram)

a) Diagram Konteks

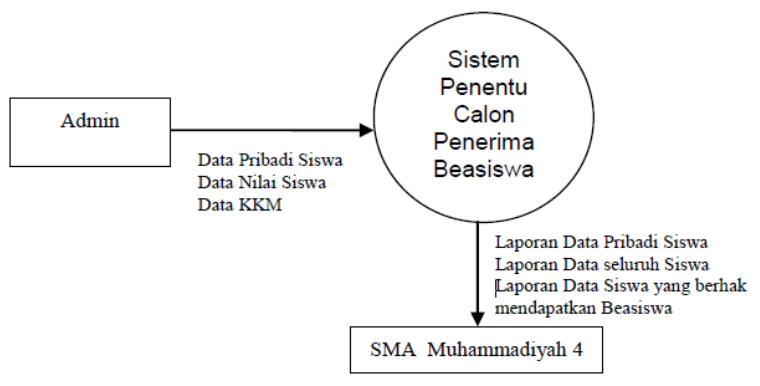

Gambar 1. Diagram Konteks

\section{b) Diagram Level Nol (Level 0)}

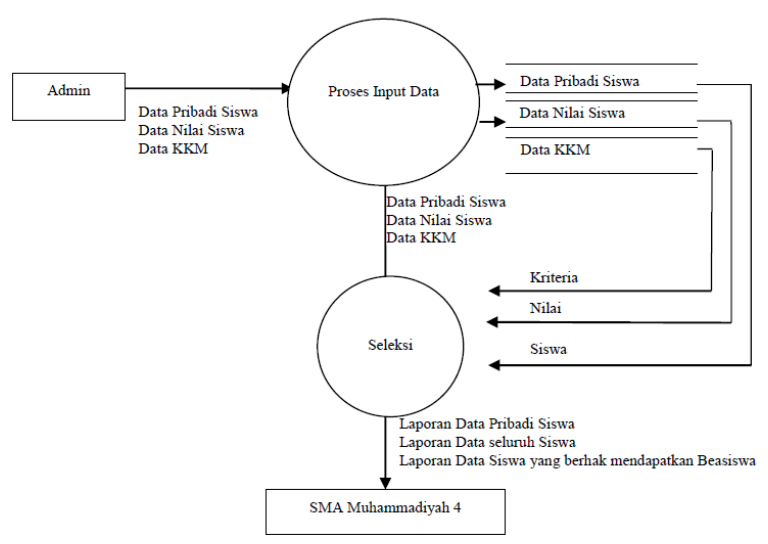

Gambar 2. Diagram Level Nol (Level 0)

2) Hierarki Plus Input Process and Output

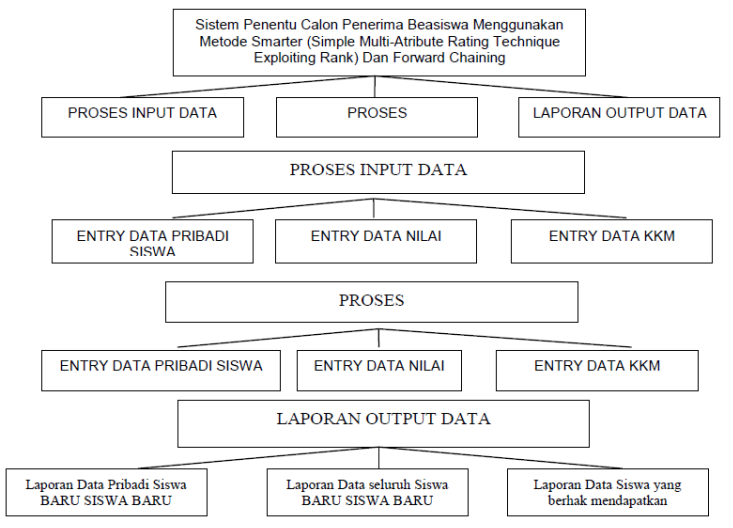

Gambar 3. HIPO (Hierarki Plus Input Process And Output) 


\section{3) Diagram Detail}
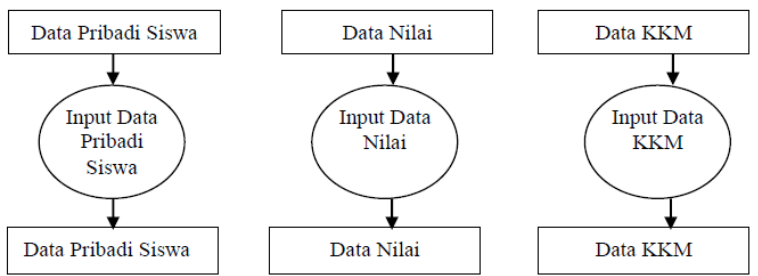

Gambar 4. Diagram Detail

\section{4) ERD (Entity Relatioanship Diagram)}

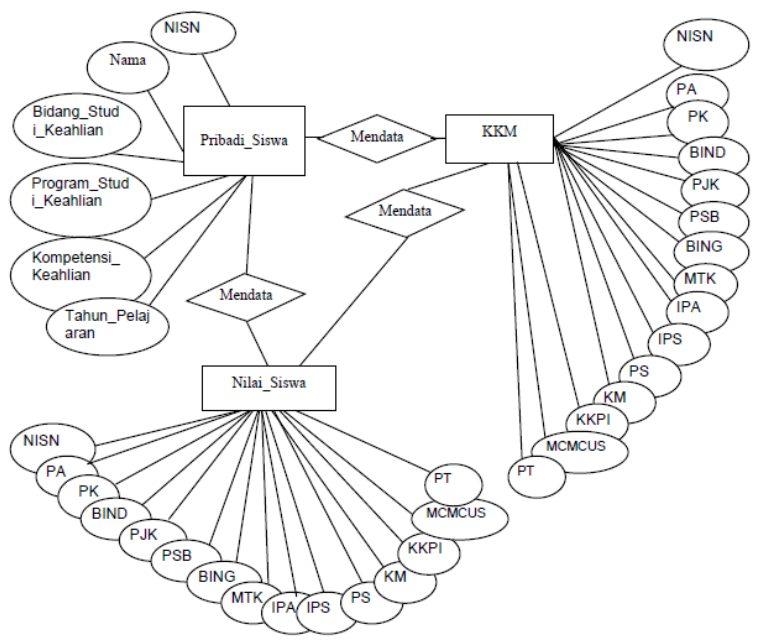

Gambar 5. Diagram ERD

\section{5) Perancangan Tabel Database}

\section{a) Tabel Data Pribadi Siswa}

Tabel 2. Rancangan Tabel Data Siswa Pribadi

\begin{tabular}{|l|l|l|}
\hline \multicolumn{1}{|c|}{ Field } & Tipe Field & \multicolumn{1}{c|}{ Keterangan } \\
\hline NISN & Text & Primary Key \\
\hline Nama & Text & Nama Siswa \\
\hline Bidang_Studi_Keahlian & Text & Bidang Studi Keahlian \\
\hline Program_Studi_Keahlian & Text & Program Studi Keahlian \\
\hline Kompetensi_Keahlian & Text & Kompetensi Keahlian \\
\hline Tahun_Pelajaran & Text & Tahun Pelajaran \\
\hline
\end{tabular}

\section{b) Tabel Data Nilai Siswa}

Tabel 3. Rancangan Tabel Data Nilai Siswa

\begin{tabular}{|l|l|l|}
\hline \multicolumn{1}{|c|}{ Field } & Tipe Field & \multicolumn{1}{|c|}{ Keterangan } \\
\hline NISN & Text & Nomor induk Standar nasional siswa \\
\hline PA & Integer & Pendidikan Agama Islam \\
\hline PK & Integer & Pendidikan Kewarganegaraan \\
\hline BIND & Integer & Bahasa Indonesia \\
\hline PJK & Integer & Pend Jasmani Dan Kesehatan \\
\hline PSB & Integer & Pend Seni dan Budaya \\
\hline BING & Integer & Bahasa Inggris \\
\hline MTK & Integer & Matematika \\
\hline IPA & Integer & IPA \\
\hline IPS & Integer & IPS \\
\hline FS & Integer & Fisika \\
\hline KM & Integer & Kimia \\
\hline KKPI & Integer & $\begin{array}{l}\text { Keterampilan Komputer dan Peng Infor- } \\
\text { masi }\end{array}$ \\
\hline MCMCUS & Integer & $\begin{array}{l}\text { Menguasai Cara Menggambar Clean Up } \\
\text { dan sisip }\end{array}$ \\
\hline MTDSM & Integer & $\begin{array}{l}\text { Menggabungkan Teks Dalam Sajian } \\
\text { Multimedia }\end{array}$ \\
\hline MDASM & Integer & Menguasai Dasar Aniasi Stop Motion \\
\hline PT & Integer & Pemrograman Terstruktur \\
\hline
\end{tabular}

c) Tabel Data Kriteria Ketuntasan Minimal

Tabel 4. Rancangan Tabel Data Kriteria Ketuntasan Minimal

\begin{tabular}{|l|l|l|}
\hline \multicolumn{1}{|c|}{ Field } & Tipe Field & \multicolumn{1}{c|}{ Keterangan } \\
\hline PA & Integer & Pendidikan Agama Islam \\
\hline PK & Integer & Pendidikan Kewarganegaraan \\
\hline BIND & Integer & Bahasa Indonesia \\
\hline PJK & Integer & Pend Jasmani Dan Kesehatan \\
\hline PSB & Integer & Pend Seni dan Budaya \\
\hline BING & Integer & Bahasa Inggris \\
\hline MTK & Integer & Matematika \\
\hline IPA & Integer & IPA \\
\hline IPS & Integer & IPS \\
\hline FS & Integer & Fisika \\
\hline KM & Integer & Kimia \\
\hline KKPI & Integer & $\begin{array}{l}\text { Keterampilan Komputer dan Peng Infor- } \\
\text { masi }\end{array}$ \\
\hline MCMCUS & Integer & $\begin{array}{l}\text { Menguasai Cara Menggambar Clean Up } \\
\text { dan sisip }\end{array}$ \\
\hline MTDSM & Integer & $\begin{array}{l}\text { Menggabungkan Teks Dalam Sajian } \\
\text { Multimedia }\end{array}$ \\
\hline MDASM & Integer & Menguasai Dasar Aniasi Stop Motion \\
\hline PT & Integer & Pemrograman Terstruktur \\
\hline
\end{tabular}

\section{Rancangan Tampilan Program}

\section{1) Rancangan Menu Utama}

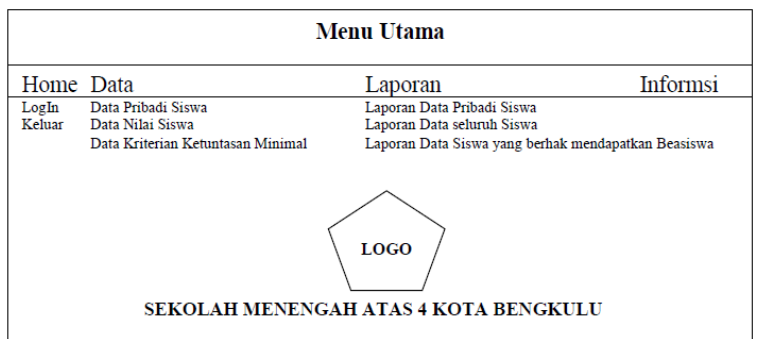

Gambar 6. Rancangan Menu Utama

\section{2) Rancangan Menu Input Data Pribadi Siswa}

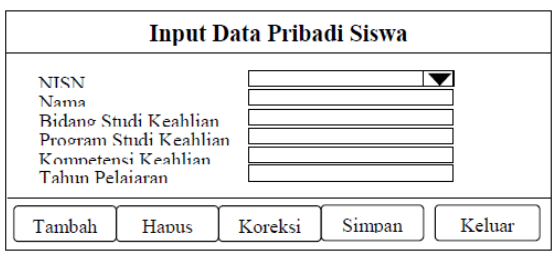

Gambar 7. Rancangan Menu Input Data Pribadi Siswa

\section{3) Rancangan Menu Input Data Nilai Siswa}

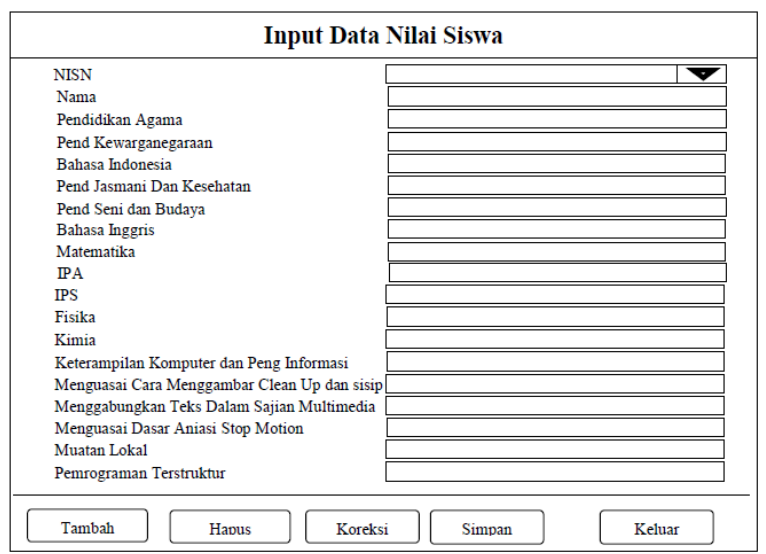

Gambar 8. Rancangan Menu Input Data Nilai Siswa 
4) Rancangan Menu Input Data Kriteria Ketuntasan Materi (KKM)

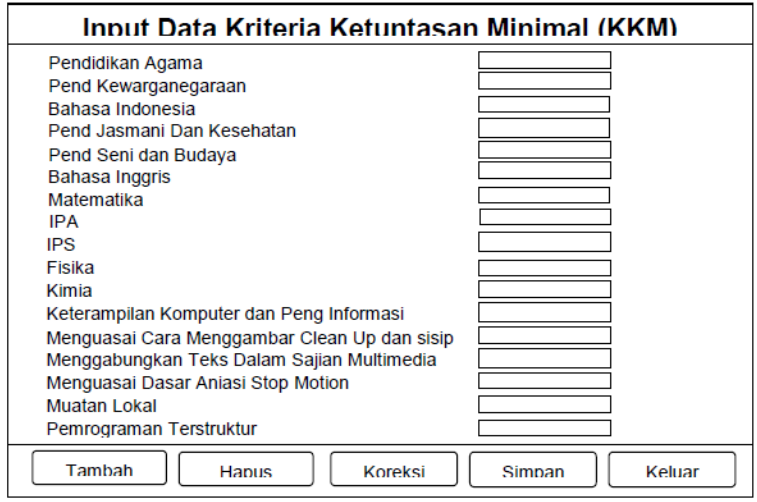

Gambar 9. Rancangan Menu Input Data Kriteria Ketuntasan Materi (KKM)

\section{5) Rancangan Laporan Data Siswa}

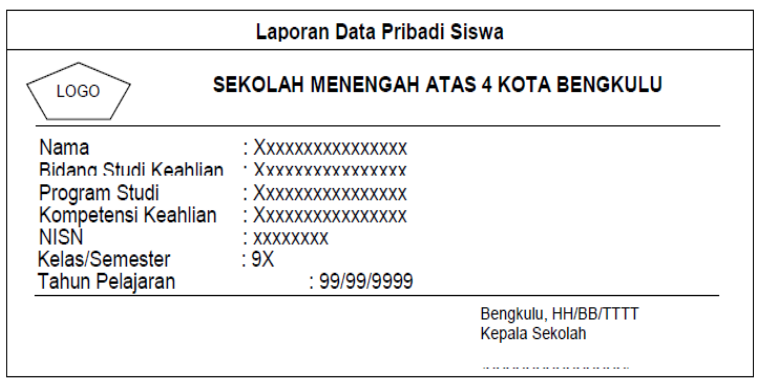

Gambar 10. Rancangan Laporan Data Siswa

\section{6) Rancangan Laporan Data Nilai Siswa}

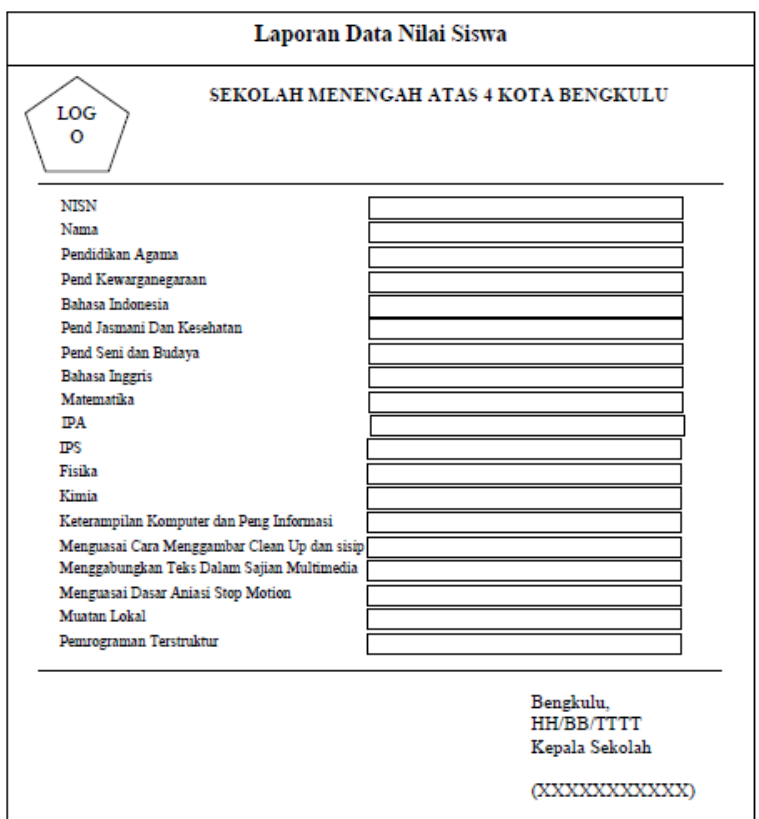

Gambar 11. Rancangan Laporan Data Nilai Siswa
7) Rancangan Laporan Data Siswa Yang Berhak Menerimah Beasiswa

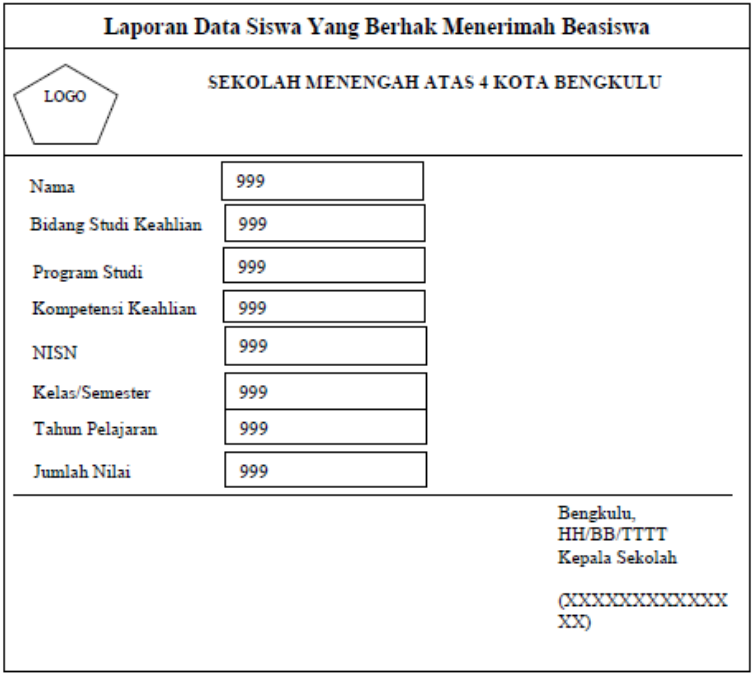

Gambar 12. Rancangan Laporan Data Siswa Yang Berhak Menerima Beasiswa

\section{HASIL DAN PEMBAHASAN}

\section{A. Form Menu Utama Pada Program Penen-} tuan Beasiswa

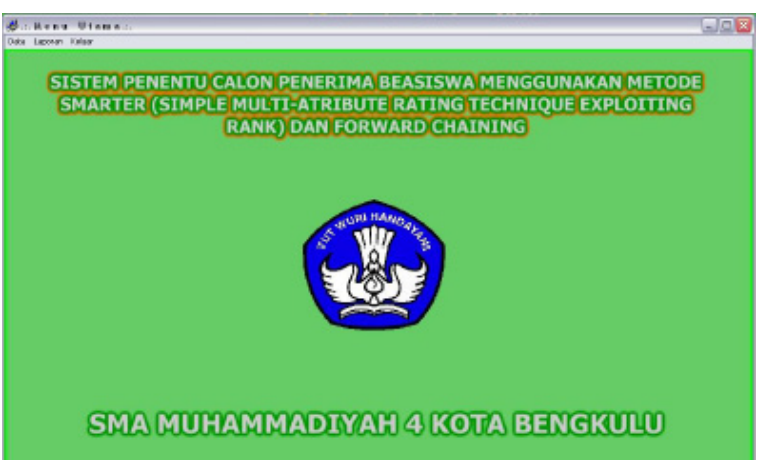

Gambar 13. Form Menu Utama

Pada form menu utama ini terdapat beberapa formpilihan yakni:

1. Form data, di dalam form data terdapat beberapa form lagi yakni form data siswa dan form seleksi data yang kegunaanya untuk memasukkan data pribadi siswa

2. Form laporan, di dalah form laporan terdapat beberapa form yakni form rekap data siswa dan form laporan data penerima beasiswa

3. Form keluar, form keluar beguna untuk menutup aplikasi apabilah sudah selesai 


\section{B. Form Data Siswa}

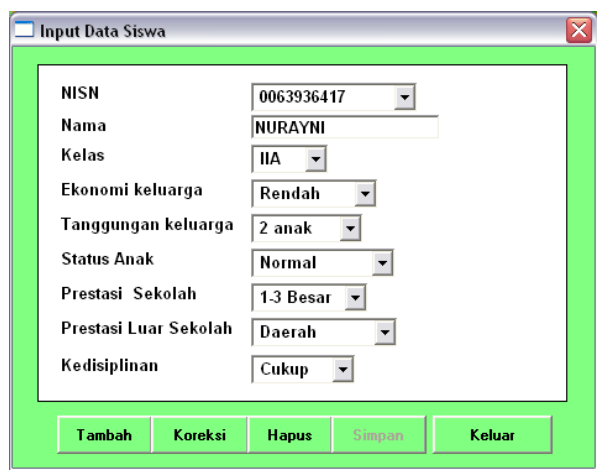

Gambar 14. Form Data Siswa

Pada form ini data siswa dimasukkan dengan beberapa kreteria yakni: nisn, nama, kelas, ekonomi keluarga, tanggungan keluarga, status anak, prestasi sekolah, prestasi luar sekolah, dan kedisiplinan.

\section{Form Proses Seleksi}

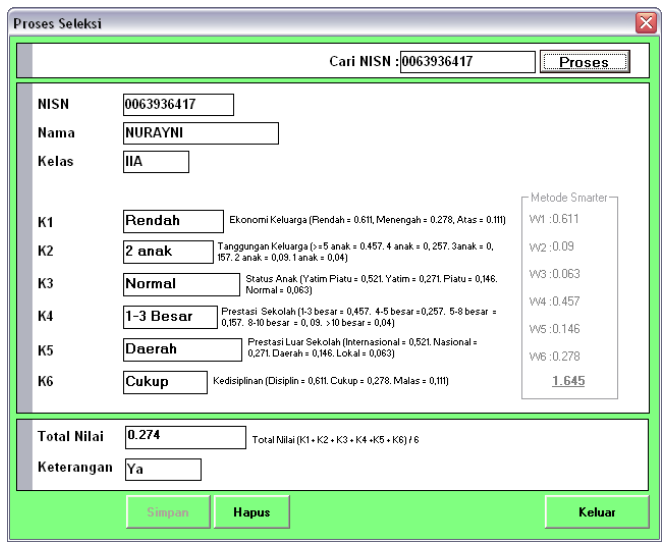

Gambar 14. Form Proses Seleksi

Pada form ini proses penyeleksian data siswa yang telah di lakukan, dimana data siswa di panggil melalui NISN siswa. Kriteria merupakan acuan yang digunakan dalam menentukan calon penerima beasiswa, semakin banyak kriteria yang digunakan maka semakin ketat seleksi yang dilakukan untuk mendapatkan beasiswa, sehingga pemberian beasiswa diharapkan benar-benar tepat sasaran, adapun kriteria dan subkriteria pada sistem penentu calon penerima beasiswa disajikan pada Tabel 5 sampai Tabel 11.
Selanjutnya nilai dari masing-masing kriteria di jumlahkan, kemudian dibagi dengan jumlah kriteria untuk penentuan kelayakan penerima beasiswa berdasarkan rule sebagai berikut:

\begin{tabular}{|l|l|l|}
\hline IF B $>0.22917$ & THEN & YA \\
IF B $<0.22917$ & & TIDAK \\
\hline
\end{tabular}

\section{Form Rekap Data}

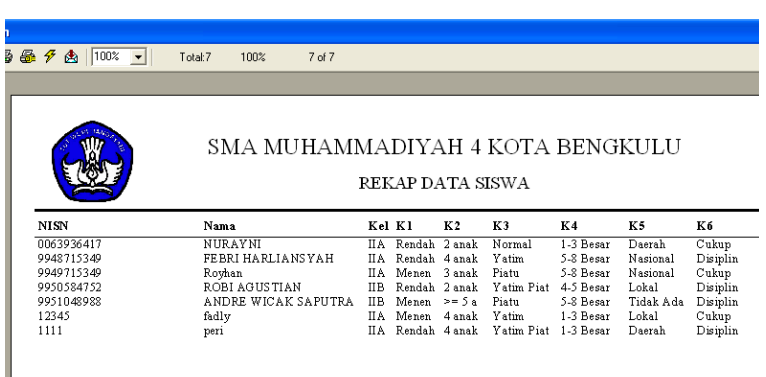

Gambar 14. Form Rekap Data

Form ini adalah tempat atau file rekapan data yang sudah di masukkan pada data siswa sebelumnya.

\section{E. Form Laporan Data Penerima Beasiswa}

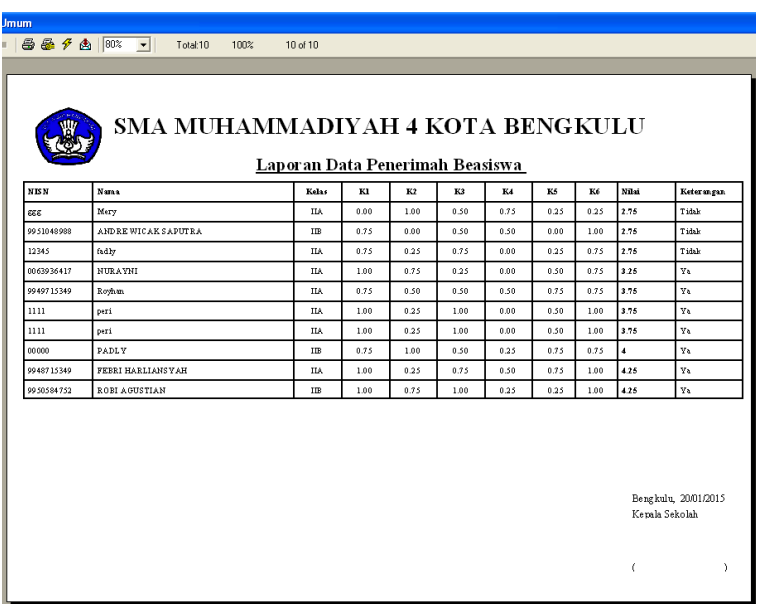

Gambar 15. Form Laporan Data Penerima

Beasiswa

Pada form ini semua datah sudah di seleksi sehingga data hasil sudah bisah di lihat siapa yang berhak menerima beasiswadan siapayang belum berhak menerima beasiswa tersebut. 
Tabel 5. Kriteria dan Pembobotan Seleksi

\begin{tabular}{|c|l|c|c|c|c|c|c|c|}
\hline No & Kriteria & W1 & W2 & W3 & W4 & W5 & W6 & Bobot \\
\hline 1 & Ekonomi keluarga & 1 & $1 / 2$ & $1 / 3$ & $1 / 4$ & $1 / 5$ & $1 / 6$ & 0.40 \\
\hline 2 & T.keluarga & 0 & $1 / 2$ & $1 / 3$ & $1 / 4$ & $1 / 5$ & $1 / 6$ & 0.25 \\
\hline 3 & Status anak & 0 & 0 & $1 / 3$ & $1 / 4$ & $1 / 5$ & $1 / 6$ & 0.15 \\
\hline 4 & Prestasi Sekolah & 0 & 0 & 0 & $1 / 4$ & $1 / 5$ & $1 / 6$ & 0.11 \\
\hline 5 & Prestasi Luar Sekolah & 0 & 0 & 0 & 0 & $1 / 5$ & $1 / 6$ & 0.08 \\
\hline 6 & Kedisiplinan & 0 & 0 & 0 & 0 & 0 & $1 / 6$ & 0.05 \\
\hline & & \multicolumn{7}{|c|}{ Total } \\
\hline
\end{tabular}

Tabel 6. Sub Kriteria 1 (Ekonomi keluarga)

\begin{tabular}{|c|c|c|c|c|c|}
\hline No & Kriteria & W1 & W2 & W3 & Bobot \\
\hline 1 & Rendah & 1 & $1 / 2$ & $1 / 3$ & 0.611 \\
\hline 2 & menengah & 0 & $1 / 2$ & $1 / 3$ & 0.278 \\
\hline 3 & atas & 0 & 0 & $1 / 3$ & 0.111 \\
\hline \multicolumn{4}{|c|}{ Total } \\
\hline
\end{tabular}

Tabel 7. Sub Kriteria 2 (Tanggungan Keluarga)

\begin{tabular}{|c|c|c|c|c|c|c|c|}
\hline No & Kriteria & W1 & W2 & W3 & W4 & W5 & Bobot \\
\hline 1 & $>=5$ anak & 1 & $1 / 2$ & $1 / 3$ & $1 / 4$ & $1 / 5$ & 0.457 \\
\hline 2 & 4 anak & 0 & $1 / 2$ & $1 / 3$ & $1 / 4$ & $1 / 5$ & 0.257 \\
\hline 3 & 3 anak & 0 & 0 & $1 / 3$ & $1 / 4$ & $1 / 5$ & 0.157 \\
\hline 4 & 2 anak & 0 & 0 & 0 & $1 / 4$ & $1 / 5$ & 0.09 \\
\hline 5 & 1 anak & 0 & 0 & 0 & 0 & $1 / 5$ & 0.04 \\
\hline \multicolumn{7}{|c|}{ Total } \\
\hline
\end{tabular}

Tabel 8. Sub Kriteria 3 (Status Orang Tua)

\begin{tabular}{|c|c|c|c|c|c|c|}
\hline No & Kriteria & W1 & W2 & W3 & W4 & Bobot \\
\hline 1 & Yatim Piatu & 1 & $1 / 2$ & $1 / 3$ & $1 / 4$ & 0.521 \\
\hline 2 & Yatim & 0 & $1 / 2$ & $1 / 3$ & $1 / 4$ & 0.271 \\
\hline 3 & Piatu & 0 & 0 & $1 / 3$ & $1 / 4$ & 0.146 \\
\hline 4 & Normal & 0 & 0 & 0 & $1 / 4$ & 0.063 \\
\hline \multicolumn{4}{|c|}{ Total } \\
\hline
\end{tabular}

Tabel 9. Sub Kriteria 4 (Prestasi Sekolah)

\begin{tabular}{|c|c|c|c|c|c|c|c|}
\hline No & Kriteria & W1 & W2 & W3 & W4 & W5 & Bobot \\
\hline 1 & $1-3$ besar & 1 & $1 / 2$ & $1 / 3$ & $1 / 4$ & $1 / 5$ & 0.457 \\
\hline 2 & $4-5$ besar & 0 & $1 / 2$ & $1 / 3$ & $1 / 4$ & $1 / 5$ & 0.257 \\
\hline 3 & $5-8$ besar & 0 & 0 & $1 / 3$ & $1 / 4$ & $1 / 5$ & 0.157 \\
\hline 4 & $8-10$ besar & 0 & 0 & 0 & $1 / 4$ & $1 / 5$ & 0.09 \\
\hline 5 & $>10$ besar & 0 & 0 & 0 & 0 & $1 / 5$ & 0.04 \\
\hline \multicolumn{7}{|c|}{ Total } \\
\hline
\end{tabular}

Tabel 10. Sub Kriteria 5 (Prestasi Luar Sekolah)

\begin{tabular}{|c|c|c|c|c|c|c|}
\hline No & Kriteria & W1 & W2 & W3 & W4 & Bobot \\
\hline 1 & Internasional & 1 & $1 / 2$ & $1 / 3$ & $1 / 4$ & 0.521 \\
\hline 2 & Nasional & 0 & $1 / 2$ & $1 / 3$ & $1 / 4$ & 0.271 \\
\hline 3 & Daerah & 0 & 0 & $1 / 3$ & $1 / 4$ & 0.146 \\
\hline 4 & Lokal & 0 & 0 & 0 & $1 / 4$ & 0.063 \\
\hline \multicolumn{7}{|c|}{ Total } \\
\hline
\end{tabular}


Tabel 11. Sub Kriteria 6 (Kedisiplinan)

\begin{tabular}{|c|c|c|c|c|c|}
\hline No & Kriteria & W1 & W2 & W3 & Bobot \\
\hline 1 & Disiplin & 1 & $1 / 2$ & $1 / 3$ & 0.611 \\
\hline 2 & Cukup & 0 & $1 / 2$ & $1 / 3$ & 0.278 \\
\hline 3 & Malas Total & 0 & 0 & $1 / 3$ & 0.111 \\
\hline \multicolumn{4}{|c|}{ Tal } \\
\hline
\end{tabular}

\section{F. Form Keluar}

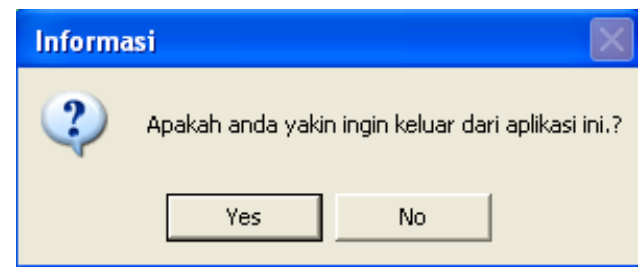

Gambar 16. Form Menu Keluar

Pada form menukeluarini adalah apabilah semua sudah selesai dan mau mengakhiri program tinggal tekam form keluar dan pilih ya atau tidak.

\section{PENUTUP}

Setelah menyelesaikan perancangan dan pembuatan aplikasi sistem pendukung keputusan serta implementasi sistem, maka diperoleh kesimpulan sebagai berikut:

1. Sistem pendukung keputusan menggunakan metode Smarter dan Forward Chaining sangat membantu bagi pengurus sekolah SMA Muhammadiyah 4 Kota Bengkulu dalam proses seleksi calon penerima beasiswa.

2. Pada proses seleksi calon penerima beasiswa SMA Muhammadiyah 4 Kota Bengkulu digunakan metode SMARTER sebagai bagian dari proses perankingan yang kemudian dilanjutkan dengan proses pengecekan kesamaan hasil seleksi SMARTER menggunakan metode Forward Chaining.

\section{A. Saran}

Perangkat lunak yang dibuat pada penelitian ini masih dapat dikembangkan lebih lanjut misalnya dengan penambahan Attribut yang lebih kompleks sehingga proses seleksi calon penerima beasiswa SMA Muhammadiyah 4 Kota Bengkulu benar-benar akurat dan sesuai dengan siswa yang membutuhkan.

\section{DAFTAR PUSTAKA}

Citra, A (2011). "Sistem pendukung pengambilan keputusan pemilihan sekolah bebas narkoba dengan menggunakan metode smarter dan oreste." Tugas Akhir Teknik Informatika. Surabaya : Universitas Pembangunan Nasional "Veteran".

Daryanto (2003). "Belajar Komputer Visual Basic", Bandung: Yrama Widya, Durkin, J.(1994). "Expert Systems Design and Development." New Jersey: Prentice Hall International Inc.

Honggowibowo, A.S. 2009. "Sistem Pakar Diagnosa Penyakit Tanaman Padi Berbasis Web dengan Forward dan Backward Chaining." Jurnal TELKOMNIKA 7,3:187-194

Kusumadewi, Sri.(2003). "Artificial intelligence teknik dan aplikasinya." Yogyakarta : Graha Ilmu. 
Kusrini.(2008). Aplikasi Sistem Pakar Menentukan Faktor Kepastian Pengguna dengan Metode Kuantifikasi Pertanyaan. Yogyakarta : Andi Offset

Mulyono, Hasyim ST (2008). “Buku Pintar Komputer.” Jakarta : Kriya Pustaka

Rudi, Moh. Ubaidillah, Achmad (2014). "Sistem penentu calon penerima beasiswa iksass Menggunakan metode smarter \& forward chaining”. Journal online (diakses 16 September 2014)

Setiawan. Ade.(2011). Rapid Application Development, Sistem Informasi Jakarta: Universitas Gunadarma..

Tutik, G.A., Delima, R. dan Proboyekti, U. 2009. "Penerapan Forward Chaining Pada Program Diagnosa Anak Penderita Autisme." Jurnal Informatika 5,2. 